\title{
Choices for Federal Spending and Taxes
}

\author{
DOUGLAS W. ELMENDORF*
}

Although weakness in the U.S. economy is an important factor in current federal budget deficits, even robust growth will leave unsustainable deficits unless there are major changes in federal policies. Moreover, deficits cannot be eliminated by reversion to past tax and spending policies. This paper explores the causes and magnitudes of the projected deficits and the choices that must be faced for the federal budget to regain a sustainable path.

Business Economics (2012) 47, 161-164.

doi: $10.1057 /$ be. 2012.20

Keywords: federal spending, taxes, fiscal policy, discretionary spending, health care spending, federal debt

he federal budget deficit this year will be well over a trillion dollars for the fourth year in a row. An important factor behind those large deficits has been the very weak economy. But if the country maintains its current spending and tax policies, even an improving economy will still leave the deficit so large that debt will continue to rise much faster than GDP. That cannot go on indefinitely: The country will need to change policies. Moreover, the country cannot go back to policies it followed in the past. Given the aging of the population and rising costs for health care, the combination of budget policies that worked in the past will not work in the future. Instead, the country will need to adopt a new combination of policies that will be starkly different from our past policies. There is no choice about that. However, lawmakers and citizens have a choice about the ways the policies will be different, and that is the subject of these remarks.

Figure 1 shows that under the Congressional Budget Office's (CBO's) baseline projections, deficits fall to about $1 \frac{1}{2}$ percent of GDP for much of the coming decade. It is critical to understand that our baseline projections are conditioned on current law-not because CBO expects there will be no changes in law but because this approach provides a benchmark against which potential changes can be measured. This projection understates the budgetary challenges the country faces, because current law includes significant changes to recent or current policies that many lawmakers say they will not let happen.

To show the consequences of maintaining what many people would think of as current policies, CBO developed projections under an "alternative fiscal scenario." That scenario incorporates the following assumptions:

- First, all expiring tax provisions (other than the payroll tax reduction) are extended. This includes extending most of the tax cuts enacted originally in 2001, 2003, and 2009.

- Second, the alternative minimum tax (AMT) is indexed for inflation after 2011.

- Third, Medicare's payment rates for physicians' services are held constant at their current level (rather than dropping sharply as scheduled in current law).

- And, fourth, the automatic spending reductions required by last year's Budget Control Act do not take effect (although the original caps on discretionary appropriations in that act remain in place).

Presentation at the NABE Washington Policy Conference, March 26, 2012. The numbers discussed here refer to CBO's estimates as of March 2012, when these remarks were presented.

*Douglas W. Elmendorf is the eighth Director of the Congressional Budget Office (CBO). As such, he oversees the agency's work in providing objective, insightful, timely, and clearly presented information about budget and economic issues. Before he came to the $\mathrm{CBO}$, Elmendorf was a senior fellow in the Economic Studies program at the Brookings Institution. He was previously an assistant professor at Harvard University, a principal analyst at the Congressional Budget Office, a senior economist at the White House's Council of Economic Advisers, a deputy assistant secretary for economic policy at the Treasury Department, and an assistant director of the Division of Research and Statistics at the Federal Reserve Board. 
Figure 1. Deficits or Surpluses, Actual and Projected (Percentage of GDP)

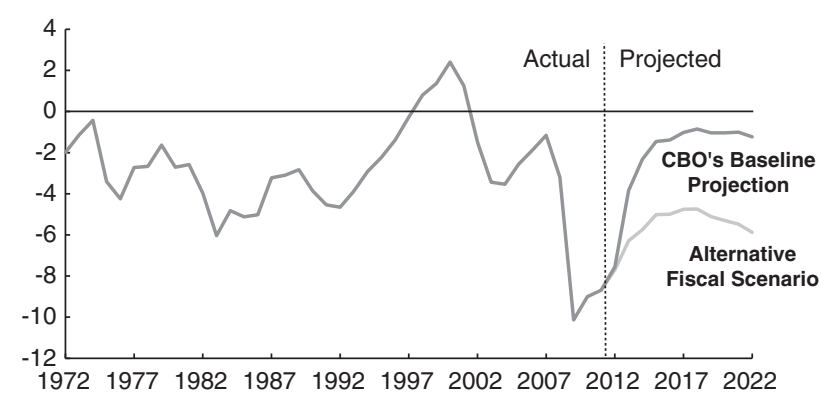

Source: Estimates from CBO's Updated Budget Projections: Fiscal Years 2012 to 2022 (March 2012).

Under that alternative fiscal scenario, deficits over the next decade would be much larger than in the baseline - averaging $5 \frac{1}{2}$ percent of GDP and totaling \$11 trillion. Figure 2 shows that under this alternative scenario, federal debt held by the public would climb on an unsustainable path, reaching 93 percent of GDP in 2022, the highest figure since just after the Second World War. Thus, under current policies, the country is quickly heading into territory that is unfamiliar to the United States - and to most other developed countries as well.

Yet, the country cannot go back to the past combination of tax and spending policies. One reason is the aging of the population: With the retirement of the baby boom generation now under way, the number of people age 65 or older will increase by about one-third in the next 10 years. The other main reason is rising costs for health care per beneficiary: During the past 25 years, health care spending per person in this country has increased nearly 2 percentage points faster per year than GDP per person.

As a result of those factors and others, outlays for Social Security and the major federal health care programs-Medicaid, Medicaid, the Children's Health Insurance Program (CHIP), and subsidies to be provided through new insurance exchanges beginning in 2014-are rising rapidly. In CBO's projections for 2022 under the alternative fiscal scenario, outlays for Social Security and the major federal health care programs are projected to be 12.8 percent of GDP, compared with an average of 7.3 percent during the past 40 years. That increase of $5 \frac{1}{2}$ percent of GDP is why the country cannot repeat past policies.
Figure 2. Federal Debt Held by the Public (Percentage of GDP)

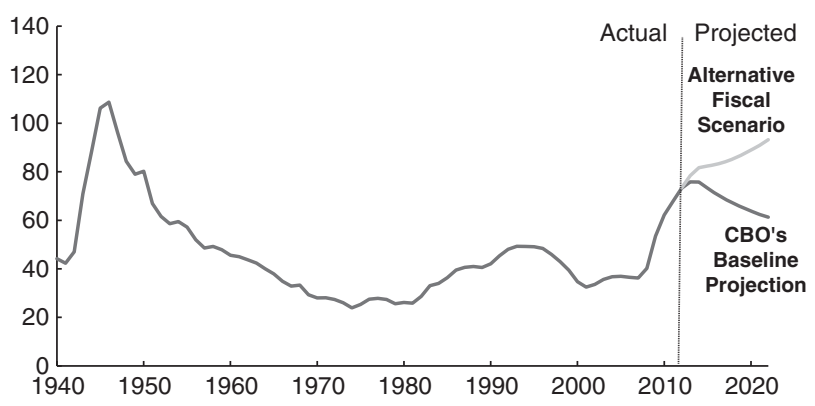

Source: Estimates from CBO's Updated Budget Projections: Fiscal Years 2012 to 2022 (March 2012).

Instead, the country will need to adopt a new combination of tax and spending policies. Achieving a sustainable federal budget will require the United States to deviate from the policies of the past several decades in at least one of the following ways:

- raise federal revenues significantly above their average share of GDP;

- make major changes to the sorts of benefits provided for Americans when they become older; or

- substantially reduce the role of the rest of the federal government relative to the size of the economy.

Indeed, the last of these three will occur by the end of the coming decade under current law and, to a slightly lesser extent, under the alternative fiscal scenario. Let's see why.

Federal spending apart from interest payments on the debt is divided into two broad categories: mandatory spending, which consists primarily of benefit programs, and discretionary spending, for which policymakers decide each year how much money to provide.

The Budget Control Act enacted last year set annual caps on discretionary funding. Under those original caps, and assuming the spending reductions required by the caps were applied proportionally to defense and nondefense funding, defense spending would drop to 3.2 percent of GDP by 2022, as shown in Figure 3. That would be nearly the lowest share seen in the past 40 years. Nondefense discretionary spending would drop to 2.8 percent of GDP by 2022 , below the lowest share seen in the past 40 years. Most mandatory spending is for Social Security and the major health care 
Figure 3. Discretionary and "Other Mandatory" Spending, Historically and Under the Alternative Fiscal Scenario (Percentage of GDP)

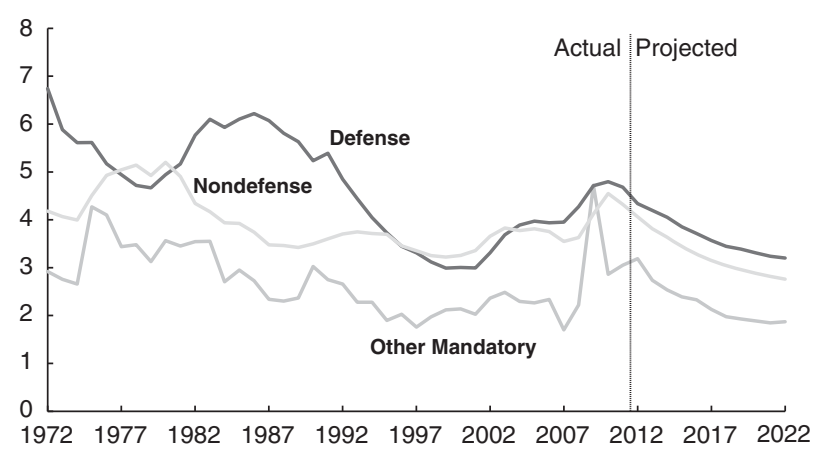

Source: Estimates from CBO's Updated Budget Projections: Fiscal Years 2012 to 2022 (March 2012). "Other Mandatory" includes programs designed to provide income security, such as the Supplemental Nutrition Assistance Program and unemployment compensation; retirement benefits for civilian and military federal employees; benefits for veterans; support for agriculture; and other activities. Estimates incorporate the assumption that the automatic spending reductions required by the Budget Control Act do not take effect, although the original caps on discretionary appropriations remain in place and are met through proportional reductions in defense and nondefense discretionary budget authority.

programs; I will come back to those shortly. For all other mandatory programs, modest increases in nominal terms coupled with steady economic growth would reduce spending to 1.9 percent of GDP in 2022, nearly the lowest share for that spending seen in the past 40 years.

Altogether, federal spending apart from Social Security, the major federal health care programs, and interest would be 7.8 percent of GDP in 2022 . That would be the lowest share in more than 40 years and about two-thirds of its average share over that period. Thus, the country is already on track to substantially reduce spending for most federal activities relative to the size of the economy compared with the experience of the past several decades.

However, that substantial reduction would not be enough to offset the increased burden on the budget from rising spending for Social Security and the major federal health care programs. Moreover, net interest on the debt would be higher than in the past because there would be much more debt. Putting all of the pieces of the budget together, total outlays under the alternative fiscal scenario are projected to be higher relative to GDP than in the past, as shown in Figure 4.

At the same time, under the alternative fiscal scenario, all expiring tax provisions (other than
Figure 4. Components of the Federal Budget as Shares of GDP: 1972-2011 Average and 2022 Projection Under the Alternative Fiscal Scenario (Percentage of GDP)

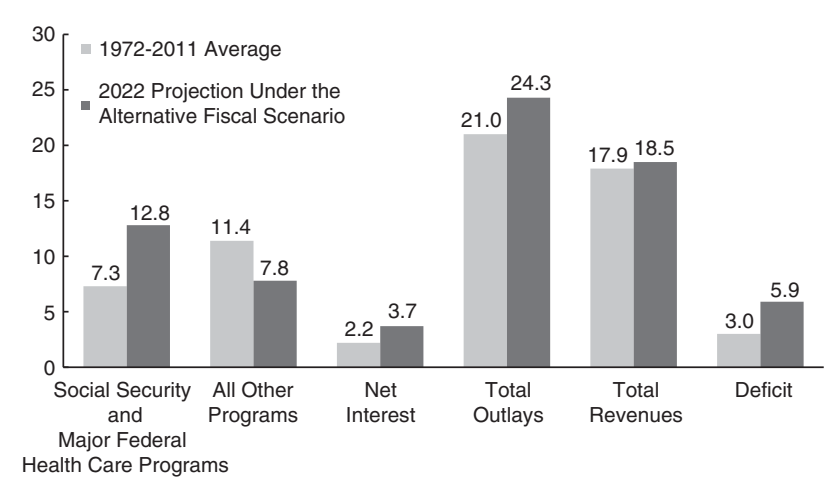

Source: Estimates from CBO's Updated Budget Projections: Fiscal Years 2012 to 2022 (March 2012).

the payroll tax reduction) would be extended and the AMT would be indexed for inflation after 2011. As a result, total revenues are projected to be close to their 40-year average in 2022. Combining spending and revenues, the budget deficit under this scenario is projected to be 5.9 percent of GDP that year, a clearly unsustainable level.

To keep debt from rising relative to GDP, the deficit in 2022 would need to be about $3 \frac{1}{2}$ percent of GDP smaller than under the alternative fiscal scenario- or about $\$ 900$ billion smaller. If changes in policy started to take effect soon but were phased in gradually, interest savings might be about $\$ 150$ billion. Then, if other spending was left at two-thirds of its average share of GDP during the past 40 years, the changes in Social Security, health care programs, and taxes would need to total about $\$ 750$ billion in 2022 .

If the changes occurred entirely in Social Security and health care programs, the cuts would be about one-quarter of the amount that would be spent without policy changes. If the changes occurred entirely in taxes, the increases would be about one-sixth of the amount that would be collected otherwise.

Those are very large changes. Moreover, although I am focusing here on 2022, the required changes become even larger if one looks further into the future. For example, Chairman Ryan's ${ }^{1}$ long-term budget proposal released this spring

\footnotetext{
${ }^{1}$ Congressman Paul Ryan is the Chair of the House Budget Committee.
} 
would maintain revenues at about 19 percent of GDP, and to achieve a small surplus in 2040, he would reduce Medicare spending in that year by about one-quarter relative to current policies, reduce health care subsidies for low-income people in that year by about three-quarters relative to current policies, and reduce all other noninterest spending apart from Social Security in that year by about 40 percent relative to current policies. An alternative approach to putting debt on a sustainable long-run trajectory is embodied in the extended baseline scenario that CBO examines regularly. This scenario is an extrapolation of current law, under which revenues in 2040 would be about a third again as large relative to GDP as their average during the past 40 years.

Where does that leave us? Let me summarize my comments today.

To put the federal debt on a sustainable path, the country needs to change policies in significant ways. All federal spending apart from Social Security, the major federal health care programs, and interest is on track to be smaller relative to GDP by 2022 than at any point in the past 40 years - and only about two-thirds of its average share of GDP during that period. If that outcome is achieved, putting federal debt on a sustainable path still requires changes in Social Security, the major federal health care programs, and taxes that amount to about $\$ 750$ billion in 2022.

To assess the magnitude of that challenge, one can think of two broad choices:

- If lawmakers were to extend the expiring tax provisions (other than the payroll tax reduction) and index the AMT for inflation, as described in the alternative fiscal scenario, they would need to cut spending on Social Security and the major federal health care programs by about one-fourth. Because most of such spending goes to people over age 65 , a cut of that magnitude would represent a major change to the sorts of benefits provided for Americans when they become older.

- Alternatively, if lawmakers did not change spending on Social Security and the major federal health care programs, they would need to increase tax revenue by about one-sixth. Such an increase would raise federal revenues significantly above their average share of GDP in the past several decades. 